\title{
FINANCIAL ANALYSIS OF ENRICHMENT MODEL USING TIMBER AND NON-TIMBER PRODUCTS OF SECONDARY REMNANTS IN THE ATLANTIC FOREST $^{1}$
}

\author{
Thais Ferreira Maier ${ }^{2 *}$, Rubens de Miranda Benini², Cristina Fachini ${ }^{3}$ and Paulo José Alves de Santana ${ }^{2}$ \\ ${ }^{1}$ Received on 11.04.2018 accepted for publication on 02.10.2018. \\ ${ }^{2}$ The Nature Conservancy do Brasil, São Paulo, SP-Brasil. E-mail:<tferreira@tnc.org>, <rbenini@tnc.org>and <psantana@tnc.org>. \\ ${ }^{3}$ Instituto Agronômico de Campinas, Centro de Ação Regional, Capão Bonito, SP-Brasil. E-mail: <cfachini@iac.sp.gov.br>. \\ * Corresponding author.
}

\begin{abstract}
Socio-economic aspects can limit the expansion of ecological restoration. One alternative to address this question is the development of restoration models that generate income to farmers in addition to the benefits from conservation itself. We designed and implemented the initiative "Sustenta A Mata," a project developed by The Nature Conservancy and supported by the Brazilian Development Bank (BNDES), to generate economic and social benefits for the communities involved. This study aims to analyze the financial viability of the enrichment restoration initiative in forest remnants based on a 30 year projection. The project was implemented on 17 hectares of land that included timber and non-timber species with a focus on the Juçara Palm (Euterpe edulis Mart.) for the production of fruit. Estimated earnings come from both the production of timber and juçara fruits. We considered input, equipment and labor costs for implementation, maintenance, and harvesting. For the economic analysis we used the following criteria: Net Present Value (NPV); Return on Investment (ROI); Benefit/Cost Ratio (B/C), and Payback. From these indicators the following values were obtained as results: US\$4,040.80 of NPV, 13 percent of ROI, 1.59 of B/C and a 13-year Payback. These positive results for the aforementioned indicators reveal that the use of the enrichment restoration initiatives utilized in this project may contribute to the economic viability of the endeavor, contributing to a greater sustainability in rural areas.
\end{abstract}

Keywords: Euterpe edulis Mart; Native species; Restoration economy.

\section{ANÁLISE FINANCEIRA DO MODELO DE ENRIQUECIMENTO UTILIZANDO PRODUTOS MADEIREIROS E NÃO-MADEIREIROS EM REMANESCENTES SECUNDARIOS DA MATA ATLÂNTICA}

\begin{abstract}
RESUMO - Os aspectos socioeconômicos podem limitar a expansão da restauração ecológica. Uma alternativa para esta questão é o desenvolvimento de modelos que geram renda para os agricultores, além dos ganhos da própria conservação. Projetamos e implementamos a iniciativa "Sustenta A Mata", um projeto desenvolvido pela The Nature Conservancy e apoiado pelo Banco Nacional de Desenvolvimento Econômico e Social (BNDES), para gerar beneficios econômicos e sociais para as comunidades envolvidas. Este estudo objetiva a análise financeira da técnica de enriquecimento para restauração de remanescentes florestais, baseado em uma projeção para 30 anos. O projeto foi implementado em 17 hectares, incluindo madeiras e espécies não madeireiras com foco em juçara (Euterpe edulis mart.) para produção de frutos. As estimativas de receitas provêm da produção de frutos de juçara e madeira. Consideramos os custos de insumos, equipamentos e mão-de-obra para implementação, manutenção e colheita. Para análise econômica, utilizamos os seguintes critérios: Valor Presente Líquido (VPL); Taxa Interna de Retorno (TIR); Razão Beneficio / Custo (B/C) e Payback. Obtivemos os seguintes valores como resultado: VPL de US \$4.040,80, TIR de $13 \%$, B/C de 1,59 e payback de 13 anos. Os resultados positivos para os indicadores acima revelam que a técnica de enriquecimento para restauração pode ser uma alternativa economicamente viável, contribuindo para uma maior sustentabilidade nas áreas rurais.
\end{abstract}

Palavras-Chave: Euterpe edulis Mart; Espécies nativas; Economia da restauração. 


\section{INTRODUCTION}

Tropical forests have been razed worldwide and converted into pastures and other crop cultures because they're regarded as economically unattractive. The Brazilian Atlantic Forest is one of the most biologically diverse and threatened regions on the planet. Currently, only around 12.5 percent of the original forest cover remains (SOS Mata Atlântica, 2015). In such a scenario, one needs to restore both the removed vegetation and also those secondary forests too degraded for self-regeneration. With this in mind, forest-based products have the economic potential that would to not only allow for the conservation and maintenance of regional biodiversity but at the same time provide socio-economic improvements for the lives of the regions' inhabitants.

The juçara palm tree is considered a key specie in the Atlantic Forest biome (Reis and Kageyama, 2000). It bears socio-economic significance as it is a traditional source of heartof-palm ('palmito') and its fruits have recently gain commercial value for the production of industrialized pulp (Favreto et al., 2010). The extraction of the palm fruits to make frozen creams from its pulp is a sustainable activity for it guarantees the maintenance of the individual palm tree and increases the species profitability (Modolo and Tucci, 2014).

The production of timber through small scale agroforestry systems can also be an alternative source of income for the regions farmers as it promotes the increase of the supply of timber and the sustainable use of the land. However, public policy agents from governments in developing countries have given little to no attention to this issue (FAO, 2013; Sousa et al., 2016). The low supply of tropical timber has caused an increase in the market value of native, slowgrowth, timber species. In addition, the tendency for the increase in demand of these species safe guards their high market value (Fasiaben, 2010 ; FAO, 2013 ).

Thus, the present study aims at evaluating the financial feasibility of the harvesting of timber and non-timber products from secondary forest remnants in the Brazilian Atlantic Forest through species-enrichment techniques. This study is based on a real project implemented in 2015. The financial analysis considered a projection of 30 years, using primary market data in the first year of implementation (2016) and based on costs and gains estimates for the latter years.

\section{MATERIALAND METHODS}

The region of study is an area within the municipalities of Cajati and Barra do Turvo, located in the Vale do Ribeira (Ribeira River Valley), southeastern state of São Paulo, Brazil (Figure 1).

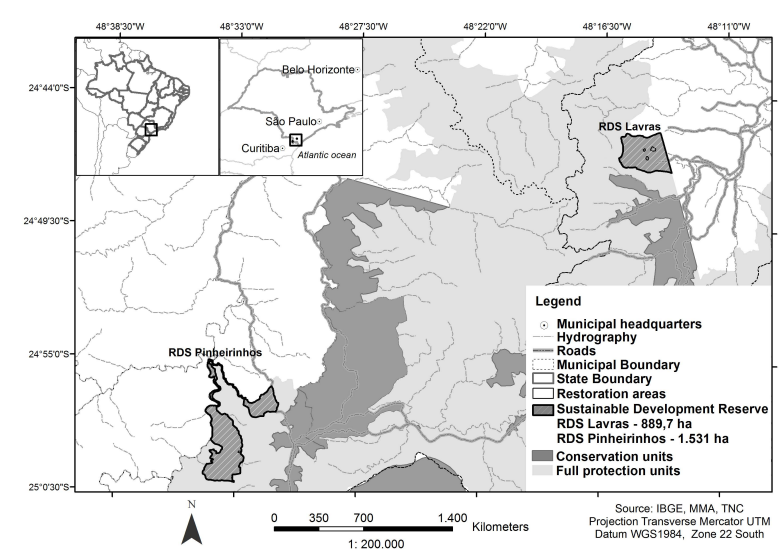

Figure 1 - Project area map: RDS Lavras (Cajati, SP) and RDS Pinheirinhos (Barra do Turvo, SP).

Figura 1-Mapa das áreas do projeto na RDS Lavras (Cajati, $S P$ ) e RDS Pinheirinhos (Barra do Turvo, SP).

The region's climate is categorized as Af, humid tropical, with year-long rains and without a discernible dry season according to Köppen-Geiger. The annual average rainfall is $1,600 \mathrm{~mm}$ and temperatures ranging from 12.1 to $34^{\circ} \mathrm{C}$ with an annual average of $24^{\circ} \mathrm{C}$ (CEPAGRI, 2016). The area's landscape is characterized by an excessively uneven ground with high slopes (IBGE, 2015) and forest formations of dense ombrophilous forests (Bim, 2012). This region is home to São Paulo's largest natural forest cover with an area of 1.2 million hectares that present a clear vocation for forestry (Lepsch, 1990). The region while having an immense ecological value for the Atlantic Forest biome presents a midrange Human Development Index (HDI) of 0.69 for its inhabitants and is considered the lowest of the state of São Paulo (Bim, 2012).

The Nature Conservancy (TNC) with support from the Brazilian Development Bank (BNDES) and in partnership with local communities, created an initiative in the municipalities of the region as part of the "Sustenta a Mata" project. The complete project was implemented in a total of 130 hectares distributed throughout the states of São Paulo, Santa Catarina and Paraná. However, the total area of the present study covers 17 hectares within the Sustainable Development Areas (RDS in Portuguese) of the communities of Lavras and Pinheirinhos (Fig. 1) that compose the Jacupiranga Conservation Mosaic. These development areas (RDS) are a unique category of Sustainable-Use Conservation Units that according to Brazilian legislation allow for

Revista Árvore. 2018;42(6):e420602 
the exploitation of components of the natural ecosystem in a sustainable fashion. In these areas, there is a recommendation for the use of non-timber forest products in order to generate income. Timber extraction is permitted for communal internal consumption, respecting the conservation unit's management plan (Brasil, 2000).

The applied methodology of restoration was ecological enrichment of areas consisting primarily of initial succession species with low biological diversity by the insertion of middle and late succession species. The enrichment process consists of the re-introduction of species that might be locally extinct in degraded areas and the selection of economically relevant or profitable species (Rodrigues and Gandolfi, 2004; Guerin et al., 2013).

The implemented restoration model (Figure 2) is composed of four groups: 1) Mid-term timber trees (species with medium density and harvesting time of over 20 years); 2) Long-term timber trees (species that produce high-value timber, with high density and durability, harvested after year 30); 3) Non-timber tree species (native, medicinal and fruit trees dedicated for self-consumption and alternative sources of income) and 4) Juçara palm trees (diferentiated as a potential steady income source, planted at higher densities and in exclusive planting lines).

The first group composed of mid-term growth tree species for timber contains the following specimens: Jacaranda puberula Cham., Handroanthus albus (Cham.) Mattos, Anadenanthera colubrina (Vell.) Brenan, Parapiptadenia rigida (Benth.) Brenan, Ocotea tabacifolia (Meisn.) Rohwer, Cabralea canjerana (Vell.) Mart and Cedrela fissilis Vell. The second group, composed of long-term tree species is made up of: Aspidosperma polyneuron Müll.Arg., Araucaria angustifolia (Bertol) Kuntze, Monteverdia ilicifolia (Mart. ex Reissek) Biral, Calophyllum brasiliense Cambess., Centrolobium tomentosum Guillemin ex. Benth., Copaifera langsdorffii Desf., Hymenaea courbaril L., Vitex megapotamica (Spreng.) Moldenke, Nectandra lanceolata Nees, Ocotea catharinensis Mez, Persea willdenovii Kosterm., Ocotea porosa (Nees \& Mart.) Barroso, Ocotea odorifera (Vell.) Rohwer, Cariniana estrellensis (Raddi) Kuntze, Virola bicuhyba (Schott ex Spreng.) Warb. The third group composed of native non-timber tree species contains specimens of: Annona cacans Warm., Euterpe edulis Mart., Campomanesia xanthocarpa (Mart.) O.Berg, Myrcia

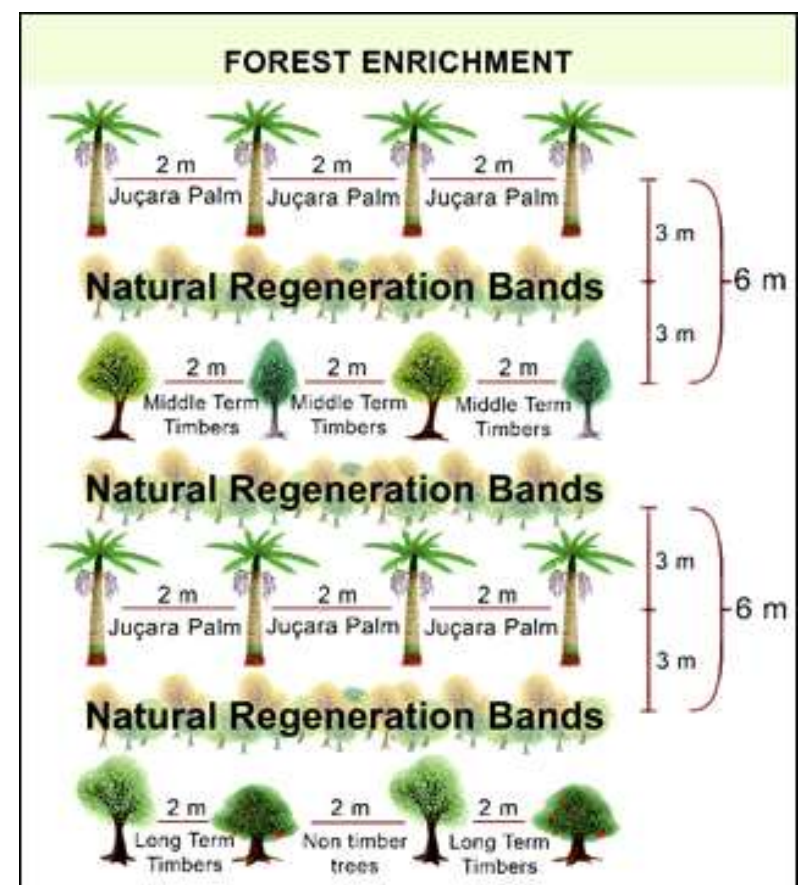

Figure 2 - Enrichment model technique with timber and nontimber species used at the Lavras RDS.

Figura 2-Modelo de enriquecimento com espécies madeireiras e não madeireiras implantado na RDS de Lavras.

guianensis (Aubl.) D.C., Eugenia uniflora L., Eugenia pyriformis Cambess., Psidium cattleianum Sabine, Campomanesia phaea (O. Berg.) Landrum, Eugenia brasiliensis Lam., Pouteria sp. and Plinia cauliflora (Mart.) Kausel.

The enrichment model focuses on the economic use of socially-biodiverse products composed of the juçara palm tree for the production of fruits for market, wood products (timber materials and firewood) for communal usage and other native fruits for selfconsumption.

The project's execution requires no alternative conservation management plan for the RDS Lavras Conservation Unit, as the unit already possesses its own plan in which allowed commercial and non-commercial activities are specified. The exploitation of forest resources for the production of timber need only be submitted for registration to the state environmental agency as this timber is for non-commercial use only. This enrichment model utilized in the project complies with the Brazilian Forest Code (Law 12,651/2012), Atlantic Forest Law (Law 11,428/2006) and with Resolution SMA- 
14 of 2014 (Brasil, 2006, 2012; SMA, 2018). Resolution SMA-14 regulates the picking and collection of fruits from species, like the Juçara Palm Tree, in Conservation Units of the state of São Paulo.

The data used for the calculations of cost during the project's implementation phase and year one are based on actual costs of production for the year 2016 in the studied area. From year 2 and on, revenue and costs are based on estimates provided by similar studies and adjusted to the local reality.

The production of Juçara fruit maybe estimated at 2.5 bunches per individual/year at approximately 3.2 kilograms of fruit per bunch (Reis, 1995; Mac Fadden, 2005; Barroso, 2009) amounting to 8 kilograms of fruits per palm tree. In order to maintain the species ecological function only 50 percent of the palm trees were considered for harvest (Pupo, 2007). A fruit yield of 70 percent was considered due to plausible production losses (Barroso, 2009). The following production forecast were considered: 70 percent of the total production capacity at year 5,85 percent at year 6 and a stable full production capacity for year 7 and on (GFA, 2014). The total fruit yield from year 7 and on is $2,500 \mathrm{~kg}$ per hectare per year. Since this enrichment model takes place in secondary forests of the Atlantic Forest Biome the appropriate edaphoclimatic conditions for the juçara's development, such as shading and moisture, were considered to be met.

The estimates for timber production considered a mean annual increment (MAI) of the trees' diameter at breast height (DBH) of 0.9 and 0.7 centimeters/year for the mid- and long-term timber species, respectively. These values were gathered from age, height and $\mathrm{DBH}$ data obtained in from experimental plantations in the Brazilian Atlantic Forest (Carvalho, 2003, 2006, 2008). The form factor considered was 0.5 while the average height was considered at 10 meters. The timber yield considered was of 50 percent in volume with the remainder discarded for use as fuel (Magalhães et al., 2007).

As the production of timber was considered for self-consumption, estimated revenue from timber for the financial analysis was set as equaling the cost of opportunity from purchasing timber elsewhere; that is, the revenue would come from the farmers not having to buy timber at the local market (Siebert, 2008). The communal timber consumption for housing structures, furniture and other needs was estimated at 9 cubic meters per family. This estimate set a timber production goal of approximately 4 cubic meters per hectares (considering a total of 17 hectares) of mid-term species for years 20, 25, 30 and a timber production of longterm species of 4 cubic meters in year 30 .

These production volumes are significantly lower than the potential production yield of the areas' introduced foreign species. However, as the legal context of land use within the project's zone of operations only allows for the exploitation of wood for noncommercial purposes, the produced timber may only be extracted for the personal use of the inhabitants within the Conservation Units. Because of this, a minor percentage of the planted trees were considered for harvesting purposes, allowing for the forest's further enrichment through the replenishment of species by the natural dispersion of the trees' seeds.

The data regarding both revenue and activities required for the projects initial implementation (planting phase) were gathered during field visits to the "Sustenta A Mata" Initiatives. The project was divided into for phases: project implementation, maintenance, harvest and product processing. For each phase the costs that we considered where: labor, equipment, expendable materials and other inputs costs. Land costs where considered to be zero as the farmers participating in the project already owned the land and its production benefits.

Prices set for the analysis of the revenues intake from the projects finished products where set at regular market prices as of September 2016. The exchange rate considered was R \$ 3.23 per 1 US Dollar. Labor costs (days/worker) where based on average wages for rural workers in the region at US\$21.67 per workday per worker.

The initial implementation phase consisted of soil liming, ant control (use of artificial baits), organic fertilization, manual preparation of planting holes, manual weeding around each sapling, and the transportation of agroforestry inputs to the site. The maintenance phase occurred until year 2 of the projects initiation, consisting of re-planting of lost saplings, selective weeding, harrowing, application of ant baits and fertilizing. The transportation of new saplings was also required.

The harvest phase comprised of the manual harvesting of the juçara fruit and the costs of timber extraction and sawing.

The harvesting of the juçara fruit required four laborers to manually pick the fruit. As one laborer is

Revista Árvore. 2018;42(6):e420602

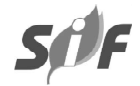


responsible for cutting the fruit bunches, two others secure a net to cushion the falling bunches in order to avoid damaging the fruit and decreasing the fruit yield. The last laborer separates the individual fruit from the fruit bunches. This harvesting method allows for 800 to 1,200 kilograms of fruits to be harvested daily (GFA, 2014). The region's harvesting period for the juçara fruit consists of the months between March and May. The considered fruit yield was 800 kilograms per day per group of laborers. The equipment utilized during the harvesting process is a small bench, climbing equipment, ropes, pruning saw, lopper and harvesting net.

After harvesting, the gathered fruits must be bagged on site and taken for processing immediately or kept in refrigerators awaiting transportation. During the bagging process the following materials are used: a 50-kilogram scale, a freezer and raffia sacks. Transportation costs were also included in the total harvesting costs (GFA, 2014).

The calculation of the equipment depreciation follows Rezende et al. (2001) by dividing the initial costs (acquisition or reposition prices) minus an estimated scrap value by the project's estimated duration. The equipment requirements for the most costly equipments (scale, freezer and climbing kits)where calculated per family, resulting in half a unit per hectare, that is to say, one unit for every two hectares, which is the average area owned and worked by each family participating in the project.

For the harvesting and transportation of wood for timber, logging yields were estimated at $4 \mathrm{~m}^{3} /$ hour/ laborer. While the timber yields (sawing) where estimated at $0.42 \mathrm{~m}^{3} /$ hour/laborer (Batista et al., 2013). The labor costs considered for the logging operations was US\$24.76 /hour/laborer and covers chainsaw depreciation, licensing, fuel, replacement chains, chainsaw operator and assistant. This harvesting of wood and processing of logs into timber was outsourced to a regional provider.

For revenue, the analysis considered only the fruit production and timber tree species introduced in the project. The study did not include revenue from the other feasible medicinal herbs and fruit trees due to the current lack of data on available market prices; we would like to highlight however that these noncommercial products where utilized by the farmers participating in the project and for their enviromental benefits. The considered market prices of in natura juçara fruits were of US $\$ 0.58 / \mathrm{kg}$ as set by regional prices (CONAB, 2016).

The considered price of fuelwood at the loader was US $\$ 11.41 / \mathrm{m}^{3}$ (SEAB, 2016). For mid-term timber, the considered price was US $\$ 333.14 / \mathrm{m}^{3}$ and for the long-term timber US $\$ 593.60 / \mathrm{m}^{3}$, based on local market research. We estimated the cost of sawn wood based on prices found in local markets from species with similar characteristics to those species utilized in the project.

The economic analysis used Net Present Value (NPV), Return on Investment (ROI), Benefit - Cost Ratio (BCR), and Payback (Gittinger, 1982) considering a 30-year time frame and ex-ante inputs and outputs.

The interest rate used for the calculations was 6 percent/year equal to interest rates of a regular saving account. This rate served as the minimum acceptable rate of return (MARR), a benchmark for the ROI and for the minimum attractiveness rate (TMA), which serves as a comparison to the IRR results.

\section{RESULTS}

The project's cash flow estimates are presented in Table 1. The cost of project implementation at year zero was calculated at US\$1,329 per hectare in year 0 . Associated cost of implementation include the purchase of tree species composed of juçara palm trees, timber producing species and other species used only for biodiversity enrichment. Labor costs were US\$568.89 and other input costs were US\$760.12. For year 1 maintenance costs amounted to US\$854.64 (US\$655.57 for labor and US\$ 199.07 for inputs) and the costs for year 2 amounted to US\$532.97 (US\$ 525.54 for labor and US\$7.53 for inputs) per hectare. Therefore, the total of the project's implementation phase was calculated at US\$2,716.62 per hectare. Throughout the project the estimated total amount of labor costs were US\$10,296.54 (69.1 percent) and inputs cost of US $\$ 4,611.74$ (30.9 percent).

Juçara harvesting costs begin in year 5 and ramp up until year 7 when fruit production stabilized. In year 5 , the necessary workforce for collecting, separating and transporting the fruits cost US\$182.04; US\$ 218.88 in year 6 and US\$277.40 in year 7. The cost of inputs in year 5 was US\$474.94; US\$106.35 in year 6, and

US\$124.63 as of year 7. The cost of inputs in year 5 where significantly higher due to the purchasing of processing equipment, such as climbing gear, weight 


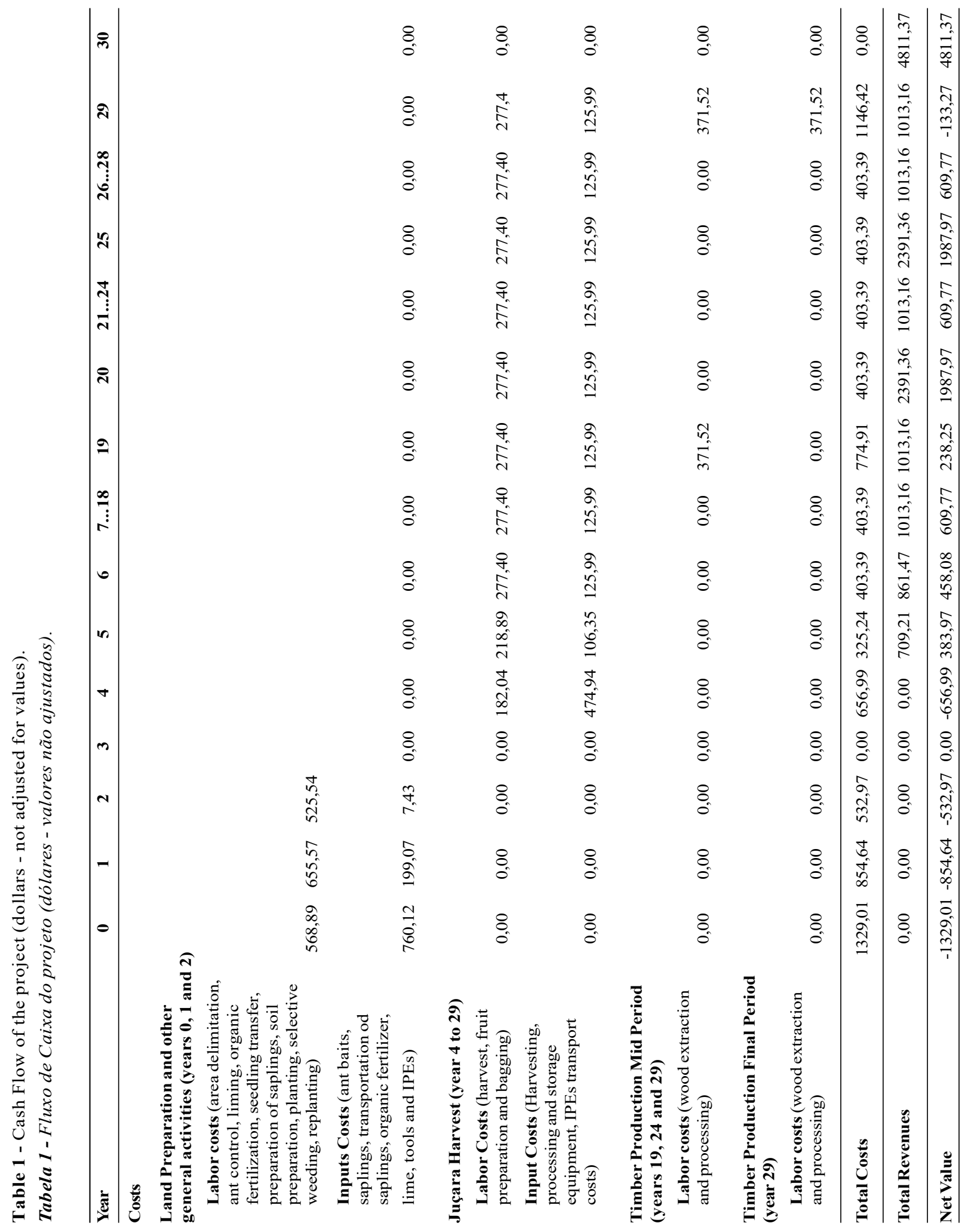

Revista Árvore. 2018;42(6):e420602 
scales and a horizontal freezer. The total cost of labor and inputs for fruit production reached US\$7,649.54 and US\$3,632.23, respectively.

The timber harvest and processing costs were US\$371.51 in years 20 and 25 and labor costs of US\$ 743.04 in year 30 .

Except for implementation costs (seedlings and fertilizers, among others), there were no other input costs for timber production, only labor costs during harvesting (as the outsourced service provided the needed equipment). Since firewood is a by-product, the study did not account for the costs of labor and inputs in its production (harvest).

Figure 3 presents a graphical representation of labor force demand per period, per hectare; we noted an increase in demand in year 0 when the project was initiated, followed by years 1 and 2 when maintenance began. From year 5 and on, labor demands increase gradually until year 7 and stabilize due to the demands of the juçara harvest. Peaks are noted in years 20, 25 and 30 due to the heightened labor requirements for wood extraction and processing.

Regarding revenue distribution, the juçara production generated US\$709.21 in year 5, US\$861.47 in year 6 , and US\$1,013.15 in year 7 and on. Timber production revenues brought in US\$1,332.59 per year with the extraction of mid-term trees in years 20,25 and 30 and long-term species contributed US $\$ 2,374.40$ in year 30. Firewood, as a byproduct of timber processing,

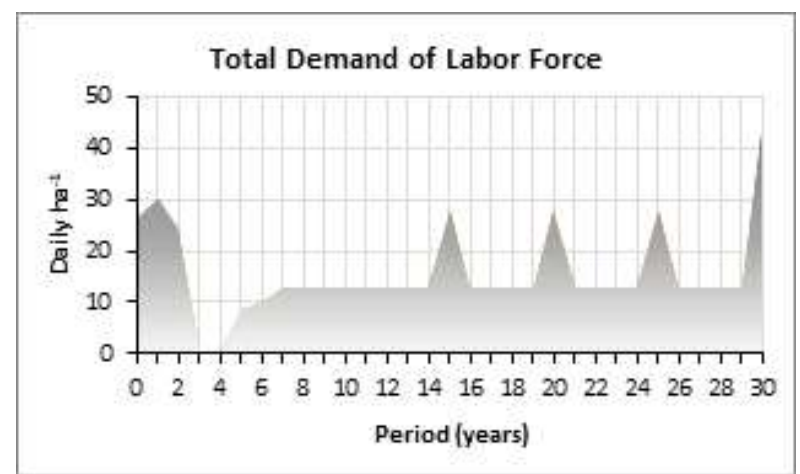

Figure 3 - Total daily labor demand per year per hectare for the planting and management of the enrichment model in the Lavras RDS.

Figura 3 -Demanda total de mão de obra em diárias por ano por hectare para implantação e manejo do modelo de enriquecimento na RDS de Lavras . both from mid- and long-term species, amounted to US\$ 45.61 for years 20 and 25, and US\$ 91.22 for year 30 . It is worth noting that timber revenues correspond to what farmers did not have to spend since they used timber available in their properties (opportunity cost), as previously explained.

The juçara fruit production generated greater revenues and costs when compared to timber production, which reinforces the focus on juçara fruit production with timber as complementing revenue. The total revenue from the juçara fruit amounted to US $\$ 25,886.47$ with overall costs of US\$11,281.77. Overall revenues from mid-term timber species amounted to US\$3,997.78 and total costs were US\$1,274.97. Long-term species, on the other hand amounted to US\$2,374.40 in revenue with a total cost of US\$445.28. Finally, firewood production brought in an estimated revenue of US\$182.44 and no costs where associated as firewood is a byproduct of timber production.

Considering the estimated cash-flow, the project's break-even point is year 13 when accumulated revenues adjusted for a 6 percent yearly rate, surpasses the accumulated and adjusted costs (payback). Figure 4 is the graphical cash flow showing the pattern of total accumulated costs and revenues, adjusted for the 30year time scale.

The economic analysis of global results show that the project is economically viable. The Net Present Value (NPV) is greater than zero at US\$4,040.80 and

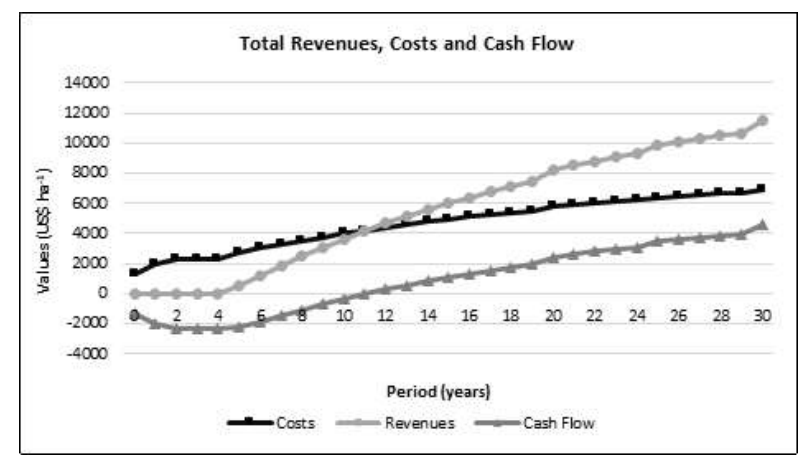

Figure 4 - Accumulated cash flow (total costs and revenues, adjusted for inflation) of the enrichment project model in a 30 year horizon.

Figura 4 - Fluxo de caixa acumulado (custos e receitas totais acumulados e ajustados) do modelo de enriquecimento em horizonte temporal de 30 anos.

Revista Árvore. 2018;42(6):e420602 
an estimated return of investment (ROI) of 13 percent,. The ROI of 13 percent is greater than the minimal annual rate of return (MARR) set at 6 percent annually and the Benefits/Cost Ratio(BCR) was calculated at 1.59 $(B C R>1)$ for a 6 percent interest rate.

\section{DISCUSSION}

Overall, labor force costs are considerably higher (68.4 percent) than other costs, which demonstrate the true value of a local, knowledgeable, workforce for this type of project in areas with severe land-use restriction. It is also possible to observe that this production scheme allows for local farmers to invest in the management of secondary forest restoration with a small demand of labor force (an average of 12.8 workdays per hectare per year, with some peaks in demand in years 20,25 and 30 for log extraction). The implementation of this scheme guarantees a source of income from the sale of juçara fruit, a source of finished products from the produced timber and the enrichment of their land through the insertion of species that enhance the regions biological diversity.

The production of juçara fruit was the primary element contributing revenue for the project's financial viability, despite the lower plant density and lower harvesting rates, set by the project in order to guarantee the species ecological function (Reis, 1995). Consequently, the yearly income of US \$1,673.49 was lower than the ones obtained by Barroso (2009) and GFA (2014), which reached as high as US\$7,502.25, and between US\$2,372.49 to US\$9,616.22, respectively.

GFA(2014) presented three different plant densities: $5,000,625$ and 357 plants per hectare, of which presented ROIs of 30,21 , and 12 percent respectively. This information allows for the identification of the strict correlation between generated revenue and plant density per hectare.

In this present study, only the sale of fresh, nonprocessed fruits were considered. Although the processed juçara pulp has greater aggregate value than the in natura fruit and therefore greater revenue, it demands a larger capital investment and greater labor costs. The necessary investment for a juçara pulp processing plant with a processing capacity of $1000 \mathrm{~kg}$ per day would cost US $\$ 179,313.35$ (GFA, 2014). In 2012, pulp market prices ranged from US\$3.07 to US\$ 5.12 per kilogram, while the in natura fruit ranged from US\$0.54 to US\$1.28 per kilogram (Rede Juçara, 2012).
Regarding timber production, the harvested amounts may be considered small compared to the total amount of planted trees ( 30 individuals out of 462 or approximately 6.5 percent). This is due to the legal restrictions imposed on the area by the legislations that reign over such conservation units (Sustainable Use Conservation Unit). As the extraction of wood is only allowed for noncommercial purposes, the extracted logs would only serve to fulfill the community's internal demand (for housing and other rural improvements). The production and processing of timber presented a complimentary and indirect economic benefit for the community, as a source of good quality material became readily available for their use, instead of having the need of purchasing such timber from the local market. These types of complementary economics are also demonstrated by Malinovski et al. (2006) in an economic evaluation of forestry efforts in small farmsteads.

When compared to other studies that propose similar models, the volume of harvested wood for timber per hectare seems rather low. It differs from studies like Brienza Junior et al. (2008), Castanho Filho (2007), Fasiaben (2010), where standing tree sales are considered without any added value from processing. These studies presented larger volumes of extracted wood per hectare and therefore greater revenues, despite the fact of not having value added to the trees. However, these studies where made in areas that do not have the same legal restrictions as that of a special conservation unit, in other words, the land could function as a full-scale agroforest commercial plantation, instead of an area that engages in some restricted commercial activities yet its main focus is conservation.

In this study's case, for the 30-year outlook, the timber directed to saw-mills amounted to $16 \mathrm{~m}^{3}$ of useful timber, generating a total income of US\$20,582.16.

It is worth noting that this enrichment model allows for higher revenues regarding the timber production component whenever the area isn't in a conservation unit. However, it is also important to consider, that wood for strict commercial purposes also carry greater overall costs, than those seen in this study, possibly decreasing profitability despite the higher yields.

The project's economic viability can be increased by including other types of species that, fulfilling the ecological requirements of the conservation unit, possess shorter production cycles, increasing revenues per

Revista Árvore. 2018;42(6):e420602 
hectare per year and in turn increasing the investment's rate of return.

\section{CONCLUSION}

This model of secondary forest enrichment in the Atlantic Forest was considered economically feasible, based on an estimated 30 year projection and having as products, the juçara fruit for commercial sale and the timber for community use. The project presents alternative sources of income for communities in protected areas with restrictive land-use legislation. In many cases, the community is so financially constricted, that their presence in the area alone is not feasible further increasing the migration to cities.

It is important, to note that possible changes in the regulatory aspects that govern these types of Conservation Units could interfere in the expected revenues, by either restricting the extraction of forest products or expanding the commercial possibilities of local products. Thes small extraction rates implemmented for both fruit and trees in this economic model, attests to the importance of sustainability on all fronts, wheter they be social, environmental or economic.

The need to perfect the juçara pulp and fruit production chain in the region, should also be noted, as increasing the capacity of added value to the production would direct more income to the farmers managing the conservation and reconstruction of the area's biodiversity. On the other hand, the production of native timber trees in the Atlantic Forest requires a larger effort that calls for an increase in forest management professionals, expanded timber processing, acquisition of market data and more importantly, a less restrictive environmental legislation. These steps would assist in the sustainability of the Conservation Units through time as it would enable those living within these units to make their land into profitable endeavors.

\section{REFERENCES}

Barroso RM. Aspectos etnobotânicos e etnoecológicos da palmeira Juçara (Euterpe edulis Martius) e a produção de frutos e polpa em quintais de comunidades quilombolas do Vale do Ribeira, SP [dissertação]. Florianópolis: Universidade Federal de Santa Catarina; 2009.
Batista DC, Corteletti RB, Hegedus CEN, Dambroz GBV. Desdobro de Eucalyptus grandis com motosserra, parte 1 - análise do desempenho operacional. Ciência Florestal. 2013;23(3):471-81.

Bim OJB. Mosaico do Jacupiranga - Vale do Ribeira, São Paulo: conservação, conflitos e soluções socioambientais [dissertação]. São Paulo: Universidade de São Paulo; 2012.

Brasil. Leis e decretos no. 9.985 de 18 jul., 2000. Sistema Nacional de Unidades de Conservação daNatureza, SNUC. Diário Oficial da União, Brasília, DF. 2000.

Brasil. Leis e decretos no. 11,428 de 22 de dez. de 2006. Lei da Mata Atlântica. Brasília, DF: 2006.

Brasil. Leis e decretos no. 12,551 de 25 de maio, 2012. Código Florestal Brasileiro. Brasília, DF, 2012.

Brienza Junior S, Pereira JF, Yared JAG, MourãoJunior M, Gonçalves Galeão RR. Recuperação de áreas degradadas com base em sistema de produção florestal energético-madeireiro: indicadores de custos, produtividade e renda. Revista Amazônia: Ciência e Desenvolvimento. 2008;4(7):197-219.

Carvalho PER. Espécies arbóreas brasileiras. Brasília, DF: Embrapa Informação Tecnológica, Colombo: Embrapa Florestas; 2003. 1039p.

Carvalho PER. Espécies arbóreas brasileiras. Brasília, DF: Embrapa Informação Tecnológica; Colombo: Embrapa Florestas; 2006. 2v. 627p. (Coleção espécies arbóreas brasileiras, 2)

Carvalho PER. Espécies arbóreas brasileiras. Brasília: Embrapa Informação tecnológica; Colombo: Embrapa Florestas; 2008. 3v. 592p. (Coleção espécies arbóreas brasileiras, 3)

Castanho Filho EP. Prospecção da viabilidade econômica do Programa Estadual de Madeiras de Lei. Informações Econômicas. 2007;37(3)1-15.

Centro de Pesquisas Meteorológicas e Climáticas Aplicadas à Agricultura - CEPAGRI. Clima dos municípios Paulistas. [acessado em: 15 de mar. 2016]. Disponível em: www.cpa.unicamp.br. 
Companhia Nacional de Abastecimento - CONAB. Conjuntura Mensal - Juçara (fruto). [acessado em: 20 de set. 2016]. Disponível em: www.conab.gov.br.

Fasiaben MCR. Impacto econômico da Reserva Legal Florestal sobre diferentes tipos de unidades de produção agropecuária [tese]. Campinas: Universidade Estadual de Campinas; 2010.

Favreto R, Mello RSP, Baptista LRM. Growth of Euterpe edulis Mart. (Arecaceae) under forest and agroforestry in southern Brazil. Agroforestry Systems. 2010;80(2):303-13.

Food and Agriculture Organization of the United Nations - FAO. Advancing agroforestry on the policy agenda: A guide for decision-makers. In: Ajayi O, Detlefsen G, Place F, Torquebiau E, editors. Agroforestry Working. Rome: FAO; 2013. (Paper, n.1).

GFA Consulting Group. Plano de Negócios do Fruto da Palmeira Juçara (Euterpe edulis]. Vitória: Projeto Corredores Ecológicos - CCMA. Cooperação Financeira Alemanha/Brasil; 2014. $105 p$. [não publicado].

Gittinger JP. Economic analysis of agricultural projects. $2^{\text {nd }}$. ed. Baltimore and London: Johns Hopkins University Press; 1982. 505p.

Guerin N, Isernhagen I, Antonio DBA. Restauração ecológica das Áreas de Preservação Permanente (APP) e Reserva Legal (RL). In: Guerein N, Isernhagen I, editors. Plantar, criar e conservar: unindo produtividade e meio ambiente. São Paulo: Instituto Socioambiental; 2013. p.25-47.

Companhia Nacional de Abastecimento - CONAB. Conjuntura mensal - Juçara (fruto). [acessado em: 20 de set.de 2016]. Disponível em:

www.conab.gov.br

Instituto Brasileiro de Geografia e Estatística IBGE. IBGE Cidades. [acessado em: 13 mar. de 2015] Disponível em: www.cidades.ibge.gov.br.

Lepsch IF, Saraiva IR, Donzeli PL, Marinho MA, Sakai E, Guillaumon JR, et al. Macrozoneamento das terras da região do Rio Ribeira de Iguape, São Paulo. Boletim Científico. 1990(19):1-181.
Mac Fadden J. A produção de açaí a partir do processamento dos frutos do palmiteiro (Euterpe edulis Martius) na Mata Atlântica [dissertação]. Florianópolis: Universidade Federal de Santa Catarina; 2005.

Magalhães WLE, Dereti RM, Wilches CE. Primeiro protótipo da serraria móvel construído por meio de parceria Embrapa/Finep/Funpar/Gil: Tecnologia em processo de validação. Colombo: Embrapa Florestas; 2007. (Circular técnica, 145)

Malinovski RA, Berger R, Silva IC, Malinovski RA, Barreiros RM. Viabilidade econômica de reflorestamentos em áreas limítrofes de pequenas propriedades rurais no município de São José dos Pinhais, PR. Revista Floresta. 2006;36(2):261-74.

Modolo VA, Tucci MLS. Palmito Juçara. In: Aguiar ATE, Gonçalves C, Paterniani MEGZ, Tucci ML, Castro CEF, organizadores. Instruções agrícolas para as principais culturas econômicas. $7^{\mathrm{a}}$.ed. Campinas: Instituto Agronômico de Campinas; 2014. p.321-5. (Boletim IAC, 200)

Pupo PSS. Manejo de frutos de Palmeira Juçara (Euterpe edulis m.) para a obtenção de polpa e sementes como Produtos Florestais Não Madeireiros (PFNM) na Mata Atlântica [dissertação]. Campinas: Universidade Estadual de Campinas; 2007.

Rede Juçara. Relatório da oficina de mapeamento da cadeia de valor da polpa dos frutos da palmeira juçara e priorização de territórios. Rio de Janeiro: Ação Nascente Maquiné - ANAMA; 2012.27p

Reis A. Dispersão de sementes de Euterpe edulis Martius. (Palmae) em uma Floresta ombrófila densa Montana da Encosta Atlântica em Blumenau, SC [tese]. Campinas: Universidade Estadual de Campinas; 1995.

Reis A, Kageyama PY. Dispersão de sementes de Euterpe edulis Mart. Palmae. In: Reis MS, Reis A, editores. Euterpe edulis Mart. (palmiteiro) biologia, conservação e manejo. Itajaí: Herbário Barbosa Rodrigues; 2000. p.60-92

Rezende JLP, Oliveira AD. Análise econômica e social de projetos florestais. Viçosa, MG: Universidade Federal de Viçosa; 2001.

Revista Árvore. 2018;42(6):e420602 
Rodrigues RR, Gandolfi S. Conceitos, tendências e ações para a recuperação de Florestas Ciliares. In: Rodrigues RR, Leitão-Filho HF. Matas ciliares: Conservação e recuperação, $2^{\mathrm{a}}$ ed. São Paulo: EDUSP; 2004. p.235-46.

Secretaria da Agricultura e do Abastecimento do Paraná - SEAB. Preços Florestais: maio, 2016. [acessado em: 29 de set. de 2016]. Disponível em: www.agricultura.pr.gov.br.

Secretaria do Meio Ambiente do Estado de São Paulo - SMA. Resolução SMA no 14 de 2014. [acessado em: 14 de set. de 2018]. Disponível em: http://www2.ambiente.sp.gov.br/legislacao/ resolucoes-sma/resolucao-sma-14-2014/.
Siebert H. Economics of the environment: theory and policy. $7^{\text {th }}$. ed. New York: Springer Berlin Heilderberg; 2008. 313p.

SOS Mata Atlântica. Atlas dos remanescentes florestais da Mata Atlântica período 2013-2014. Relatório Técnico São Paulo. [acessado em: 19 de maio de 2016] Disponível em: http:// mapas.sosma.org.br/site_media/download/ atlas_2013-2014_relatorio_tecnico_2015.pdf

Sousa KFD, Detlefsen G, Virginio Filho EM, Tobar D, Casanoves F. Timber yield from smallholder agroforestry systems in Nicaragua and Honduras. Agroforestry Systems, 2016;90(2):207-18. 